means, the findings made by short-term clinical and laboratory tests on a small series of cases in Holland.

As physicians we may be satisfied that at last normal health and growth may be regained and maintained by children suffering from this disorder, but as natural historians we are left with many unsolved problems, some of which I have outlined here.

I wish to express my thanks to Dr. Wilfred Sheldon for allowing me to report on joint work on his cases.

\title{
REFERENCES
}

Andersen, D. H. (1947). \%. Pediat. 30, 564.

Anderson, C. M., Frazer, A. C., French, J. M., Gerrard, J. W., Sammons, H. G. \& Smellie, J. M. (1952). Lancet, 262, 836 .

Dicke, W. K. (1950a). Coeliakie. M.D. Thesis, University of Utrecht.

Dicke, W. K. (1950b). Congr. Ass. int. Pédiat. vi. Zurich, p. 2 I.

Gee, S. (1888). St Bart's Hosp. Rep. 24, 17.

Gibbons, R. A. (1889-9o). Edinb. med. F. 35, 32 I.

Haas, S. V. (1938). $\mathscr{F}$. Pediat, 13, 390.

Haas, S. V. \& Haas, M. P. (1950). Postgrad. Med. 7, 239.

Heubner, O. (1909). Z. Kinderheilk. 70, 667.

Herter, C. A. (1908). On Infantilism from Chronic Intestinal Infection. New York: The Macmillan Co

Howland, J. (1921). Trans. Amer. pediat. Soc. 33, I1.

Parsons, L. G. (1932). Amer. F. Dis. Child. 43, 1293.

Sheldon, W. (1948). Brit. med. F. ii, 594.

Sheldon, W. (1949). Arch. Dis. Childh. 24, 8 r.

Sheldon, W. \& Lawson, D. (1952). Lancet, 263, 902.

Still, G. F. (I918a). Lancet, ii, I63.

Still, G. F. (r918b). Lancet, ii, r93.

Still, G. F. ( $\operatorname{Ig} 8 c)$. Lancet, ii, 227.

Weijers, H. A. (r950). De vetresorptie van gezonde en zieke zuigelingen en kinderen, in het bijzonder van coeliakiepatiënten. Thesis, University of Utrecht.

\section{Statistical Aspects of Dietary Surveys}

\section{By Barnet Woolf, Department of Animal Genetics, University of Edinburgh}

Dietary surveys are widespread and numerous, and have indeed become a regular part of the policy-making apparatus of national and international governing bodies. They are very laborious and expensive. There are great variations in methods of investigation and interpretation, and in the scale of operations considered necessary. Qualitative discussions of the faults and merits of the differing techniques are available in several reviews (e.g. Bigwood, I939; (U.S.A.) National Research Council, I949; Norris, I949; Leitch \& Aitken, 1949-50). There are also quite a number of papers containing quantitative comparisons of some particular aspects of technique, or data that allow such comparisons to be made. But there seems to have been no attempt to collect these scattered quantitative findings and to use them for a balanced statistical appraisal of the relative costs, advantages and errors of different methods of conducting dietary surveys. This paper is a tentative first approach to such an operational analysis. 


\section{Kinds of error}

Let us take the simplest type of sampling survey, in which the nutritional status of some definite population group is to be assessed by investigation of a sample selection of individuals or of family units. The practical work will consist of a long sequence of steps, each contributing something to the total error. These steps, and the errors associated with them, can conveniently be grouped under five headings.

I. Sampling of persons. The sample chosen will differ by ordinary chance fluctuations from the whole population, and may also differ because of bias in the method of selection.

2. Sampling of periods. The sample units can be studied only for a limited time. The results will give an imprecise, and may give a biased, picture of their long-range nutritional status.

3. Estimation of foodstuffs eaten. Whether the dietary constituents are weighed, recorded, or elicited by questioning, errors will inevitably creep in.

4. Estimation of nutrients. Whether done by chemical analysis or calculated from tables, the translation of foodstuffs into nutrients will be subject to errors.

5. Interpretation. This heading covers a miscellaneous group of possible pitfalls. There may be mistakes in arithmetic. Inappropriate statistical methods might be used. If a standard of nutritional adequacy is adopted, it might be too high or too low, or it might not be applicable unless due allowance could be made for varying needs of different individuals. And so on.

When a survey is more complex in structure, the kinds of error to be considered will be correspondingly increased. Thus if nutritional status is to be correlated with social class or economic resources, there will be additional errors of sampling, of possible wrong assessment of income or attribution to social class, and perhaps of interpretation. If the survey is used to provide information about prices, expenditure patterns or consumption of particular foodstuffs, each of these deductions will have its own sources of error. And it must be remembered that the simplest type of survey is usually concerned with several different nutrients, which may carry quite different relative errors of estimation.

\section{The coefficient of variation}

The nutritional status of a group is usually judged by comparing its estimated average intake of a nutrient with a standard requirement. Some illustrative data from Orr (1936) are set out in Table I. The population of Britain was divided into six income groups, whose size, as a percentage of total population, is shown in the second column. The third column gives the estimated average calorie intake of each group as a percentage of the standard. Groups $I$ and 2 have deficient average intakes. The conclusion often drawn was that $30 \%$ of the population were not getting enough calories. But that would be true only if all members of a group had exactly the same intake, leading to the state of affairs shown in columns 4 and 5 of the table. This assumption of course is against all experience. In each 
Table I. Comparison of assessment of adequacy of calorie intake of a population by crude judgement and by use of the coefficient of variation assuming applicability of the incomplete $\Gamma$ distribution (Pearson, 1922) based on illustrative data from Orr (1936)

\begin{tabular}{|c|c|c|c|c|c|c|c|}
\hline \multirow[b]{3}{*}{ Group } & \multirow{3}{*}{$\begin{array}{c}\text { Percentage } \\
\text { of } \\
\text { population }\end{array}$} & \multirow{3}{*}{$\begin{array}{l}\text { Calorie intake } \\
\text { as percentage } \\
\text { of standard }\end{array}$} & \multirow{2}{*}{\multicolumn{2}{|c|}{ Crude judgement }} & \multicolumn{3}{|c|}{$\begin{array}{c}\text { Assumed c.v. }=25, \text { incomplete } \\
\Gamma \text { distribution }\end{array}$} \\
\hline & & & & & \multirow{2}{*}{$\begin{array}{l}\text { Percentage of } \\
\text { group below } \\
\text { standard }\end{array}$} & \multicolumn{2}{|c|}{$\begin{array}{c}\begin{array}{c}\text { Percentage of } \\
\text { population }\end{array} \\
\end{array}$} \\
\hline & & & $\begin{array}{c}\text { Below } \\
\text { standard } \\
(\%)\end{array}$ & $\begin{array}{c}\text { Above } \\
\text { standard } \\
(\%)\end{array}$ & & $\begin{array}{c}\text { Below } \\
\text { standard } \\
(\%)\end{array}$ & $\begin{array}{c}\text { Above } \\
\text { standard } \\
(\%)\end{array}$ \\
\hline $\mathbf{I}$ & 10 & $8_{3}$ & IO & - & $8 r$ & $8 \cdot 1$ & I. 9 \\
\hline 2 & 20 & 98 & 20 & - & 56 & $1 \mathrm{I} \cdot 2$ & 8.8 \\
\hline 3 & 20 & 105 & - & 20 & 45 & $9 \cdot 0$ & II.O \\
\hline 4 & 20 & I I I & - & 20 & 37 & $7 \cdot 4$ & $12 \cdot 6$ \\
\hline 5 & 20 & 116 & 一 & 20 & $3 \mathrm{I}$ & $6 \cdot 2$ & I3.8 \\
\hline 6 & 10 & I 18 & - & 10 & 28 & 2.8 & $7 \cdot 2$ \\
\hline Total & 100 & & 30 & 70 & & $44 \cdot 7$ & $55 \cdot 3$ \\
\hline
\end{tabular}

group there will be a spread of values about the mean. Groups with a deficient average intake might still contain members getting more than the standard; and the greater the spread about the mean, the larger the proportion of these at any given level of average intake. Similarly groups with averages above standard might contain some members with a deficient intake, greater in proportion the more the members of the group vary among themselves. If the results of a survey are to be justly interpreted, figures for averages must be supplemented by information about the spread or distribution about the mean.

The orthodox measure of relative spread is the ratio of the standard deviation to the mean. This is usually expressed as a percentage and called the coefficient of variation (c.v.). Some examples of c.v. values found in surveys are shown in Table 2. These are chosen as referring to specially homogeneous groups. The Yorkshire data (Potts, 1939) come from I62 urban and twenty-seven rural families, the nutrients being calculated per man-equivalent. The middle-class results were obtained on sixty-three men (Widdowson, 1936), sixty-three women (Widdowson \& McCance, 1936), and 435 boys and 481 girls (Widdowson, 1947). The children were of all ages from $I$ to $I 8$, there being at least twenty of either sex at each age. Widdowson gives the c.v. figures for each age group. These do not differ significantly among themselves. They have been averaged for the table, which accordingly shows the c.v. for children of like age. The last column (Hobson, 1948) refers to I I I normal pregnant primiparous women attending the antenatal clinics in Bristol. The c.v. figures are for diets less welfare food supplements, and for vitamin A also omitting intake of liver. All the figures in the table relate to observations covering $\mathrm{I}$ week, and the nutrient content of the diets was calculated from tables. The calorie and protein figures for men tend to be rather high, as would be expected from their occupational differences in dietary needs. Otherwise the 
Table 2. Coefficients of variation for intake of several nutrients in homogeneous groups

\begin{tabular}{|c|c|c|c|c|c|c|c|}
\hline \multirow[b]{2}{*}{ Nutrient } & \multicolumn{2}{|c|}{$\begin{array}{l}\text { Yorkshire working-class } \\
\text { families (Potts, 1939) }\end{array}$} & \multicolumn{4}{|c|}{$\begin{array}{c}\text { Middle-class individuals } \\
\text { (Widdowson, 1936, 1947; } \\
\text { Widdowson \& McCance, 1936) }\end{array}$} & \multirow{2}{*}{$\begin{array}{l}\text { Pregnant women } \\
\text { (Hobson, I 948) }\end{array}$} \\
\hline & Urban & Rural & Men & Women & Boys & Girls & \\
\hline Calories & 17 & 22 & 23 & 18 & 17 & 17 & I 8 \\
\hline Protein & 19 & 22 & 24 & 18 & I9 & I8 & 15 \\
\hline Animal protein & 32 & 32 & 29 & 25 & 25 & 24 & $2 \mathrm{I}$ \\
\hline Fat & 26 & 32 & 27 & 20 & 2 I & 21 & 25 \\
\hline Carbohydrate & I 5 & 23 & 25 & 25 & I9 & 20 & \\
\hline Calcium & 35 & 36 & $4 I$ & 25 & 30 & 30 & 33 \\
\hline Phosphorus & 24 & 24 & 27 & 22 & $2 I$ & 20 & 25 \\
\hline Iron & 22 & 28 & 28 & 22 & $2 x$ & 22 & \\
\hline Vitamin A & & & & & & & 30 \\
\hline Thiamine & & & & & 24 & 23 & 20 \\
\hline Riboflavin & & & & & & & 23 \\
\hline Nicotinic acid & & & & & & & 24 \\
\hline Vitamin C & & & & & 47 & 49 & 35 \\
\hline
\end{tabular}

figures are remarkably concordant. The c.v. for calories, protein and carbohydrate is round about 20 , rising to over 30 for calcium, and 40 or more for ascorbic acid. Higher c.v. figures are found when the groups studied are less homogeneous.

The distribution of nutrient-intake values is not symmetrical, and tends to become more skew the greater the c.v. Typical distribution histograms are shown in Fig. I, drawn from the data for 162 urban working-class families (Potts, 1939). They relate to the nutrients with the lowest and the highest c.v. values, carbohydrate with a c.v. of 14.7 and calcium with a c.v. of 35 . Besides giving an idea of the amount of spread implied by these c.v. values, the figure shows how a high c.v. necessarily implies skewness of the distribution. In such a distribution the mean is to the right of the median, so that if the average intake of the group is exactly at the standard requirement, more than half the individuals will be getting less than the standard amount. Further histograms are given by Widdowson (1936), Widdowson \& McCance (1936) and Hobson (1948). But the general effect of skewness may be illustrated by use of a well-tabulated theoretical formula that fits the data fairly well, the incomplete gamma-function distribution (Pearson, 1922). Given the c.v. and the adequacy of the mean intake in terms of the standard, Table 3 shows the percentage of individuals who would be getting less than the standard amount if the gamma distribution held good. The preponderance should be noted of individuals below standard values when the average intake is just adequate, and the existence of a substantial proportion of such individuals at high c.v. values even when the average intake is twice the standard or more. As a rough guide, Table 3 may be used with due discretion to assess proportions of deficient individuals when details of distributions are not recorded. For more detailed sets of values, recourse may be had to the tables by Pearson (r922). 


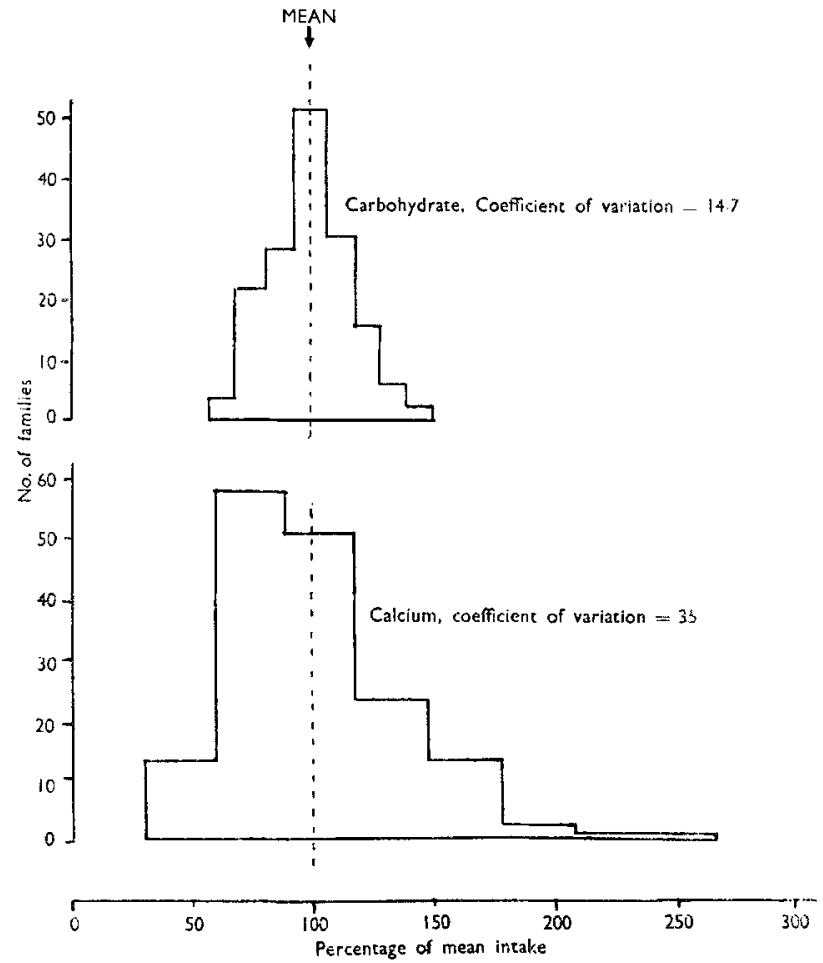

Fig. I. Frequency histograms of intake per man-unit of carbohydrate and of calcium among 162 urban families (Potts, 1939), all nutrient values being expressed as percentages of the respective mean intakes.

Purely as an example, this method has been applied to the data in Table $\mathrm{r}$. Orr (1936) gives no information about distributions, but the c.v. in each of his groups may plausibly be put at about 25. From Pearson's (1922) tables, the percentage below standard would range from $8 \mathrm{I}$ in group $\mathrm{I}$ to 28 in group 6 . The incidence of deficient diets in the population works out at about $45 \%$, compared with $30 \%$ by the crude approach. Judging an entire group by its average is obviously a fallacious way of interpreting the results. But before an alternative verdict can be accepted, there are many other kinds of error to be looked into.

\section{Errors of sampling period}

In most surveys, diets are sampled for periods of $\mathrm{I}$ week. Since any person's diet will vary from week to week, some error will be involved in taking the observed period as typical. This error might be purely random, in the sense that the deviations range evenly about the true mean. But if for any reason the diet in the observed week tends to be exceptionally high or low, as would occur if there were seasonal variations or if the effect of observation was to alter the subject's food habits, then there will also be bias. If it can be detected, it is conveniently expressed as the 
Table 3. Percentage of individuals below standard for various values of mean intake and coefficient of variation assuming the applicability of the incomplete $T$ distribution (Pearson, 1922)

\begin{tabular}{|c|c|c|c|c|c|c|c|}
\hline \multirow[t]{2}{*}{$\begin{array}{l}\text { Mean intake } \\
\text { as percentage of } \\
\text { standard }\end{array}$} & \multicolumn{7}{|c|}{ Coefficient of variation } \\
\hline & 50 & 40 & 35 & 30 & 25 & 20 & I 5 \\
\hline 50 & 96 & 98 & 99 & 100 & & & \\
\hline 60 & 90 & 94 & 96 & 98 & 99 & 100 & \\
\hline 70 & 82 & 86 & 88 & $9 \mathrm{I}$ & 94 & 97 & 99 \\
\hline 80 & 73 & 76 & 78 & 81 & 84 & 89 & 94 \\
\hline 90 & 65 & 66 & 66 & 68 & 70 & 73 & 78 \\
\hline 100 & 57 & 55 & 55 & 54 & 53 & 53 & 52 \\
\hline I IO & 49 & 46 & 44 & 42 & 39 & 34 & 28 \\
\hline 120 & 43 & 38 & 35 & $3^{x}$ & 27 & $2 I$ & 13 \\
\hline$x_{30}$ & 37 & 31 & 27 & 23 & 18 & 12 & 5 \\
\hline 140 & 32 & 26 & $2 I$ & 17 & 12 & 6 & 2 \\
\hline I 50 & 28 & 21 & I7 & 12 & 8 & 3 & I \\
\hline 200 & 14 & 8 & 5 & 2 & I & 0 & \\
\hline 250 & 8 & 3 & 2 & $\mathbf{I}$ & 0 & & \\
\hline 300 & 5 & 2 & I & 0 & & & \\
\hline
\end{tabular}

percentage deviation of the observed mean from the presumed true mean. Available evidence about these errors is rather meagre. Some typical data are shown in Table 4. McHenry, Ferguson \& Gurland (1945) induced thirty-one Canadian scientific workers to record their diets the rst week of every month for a year. Their results are inappropriately presented as an analysis of variance, from which the c.v. values can be only approximately inferred. They comment that the diets would be expected to be more uniform than among the general public, because the subjects were interested in nutrition. They did, however, plan their study so as to take account of possible seasonal variation. The other work represented in Table 4 relates to records of individual diets for 4 consecutive weeks. Boulton (1945) studied eight English children aged from I to 17 years. The entry in Table 4 gives the average c.v. Yudkin (r95 I) analysed the records for six English women: five

Table 4. Coefficients of variation of individual intakes of several nutrients from week to week

$\begin{array}{lcccc}\text { Scientists } & \begin{array}{c}\text { Children } \\ \text { (Boulton, } \\ \text { (McHenry } \text { et al. }\end{array} & \begin{array}{c}\text { Students of } \\ \text { dietetics } \\ \text { (Yudkin, } \\ \text { I945) }\end{array} & \begin{array}{c}\text { stenographers } \\ \text { and others }\end{array} \\ \begin{array}{l}\text { I945) } \\ \text { (Young, Franklin } \text { et al. }\end{array} \\ \text { Calories } & 8 & 7 \cdot 4 & \text { II } & \text { 1952) } \\ \text { Protein } & 9 & & \text { I } & 8 \\ \text { Vitamin A } & 26 & & 48 & \text { I0 } \\ \text { Vitamin C } & 26 & & \mathbf{2 2} & 36 \\ \text { Vitamin D } & & & 45 & 35\end{array}$


dietetic students and one lecturer. The average c.v. values in Table 4 are calculated from his histograms. Young, Franklin, Foster \& Steele (1952) used records for sixteen women and two men, secretaries, technicians or students at Cornell University, U.S.A. The c.v. figures in Table 4 have been inferred from their data for extreme range of variation, and must be regarded as rough approximations.

It seems that the c.v. for calories and protein is about 10 , and anything from 25 upwards for some of the vitamins whose main sources of supply are a few specialized foodstuffs. These figures apply only to individuals, and are not necessarily representative of the week-to-week variability of consumption in family units. Nor is there any information about the possible bias due to the housewife departing from her normal food routine during the period of observation. Yudkin (1951) supplies evidence that individual studies for I week may be biased from this cause. His dietetic students, recording their own diets, ate significantly more in the ist week than their presumptive normal intake, the average excess in calorie and protein intake in the rst week over the 3 subsequent weeks amounting to about $15 \%$.

\section{Errors in estimation of nutrients}

Estimation of calories and nutrients by chemical analysis is so laborious that tables of food composition are generally used, except in special small-scale inquiries. Several workers have compared tabular and analytical values, and some results are set out in Table 5. Five groups of data are included, two from England, then two

Table 5. Comparison of tabular and analytical values for the nutrient content of diets, the calculated value being expressed as a percentage of the analytical value

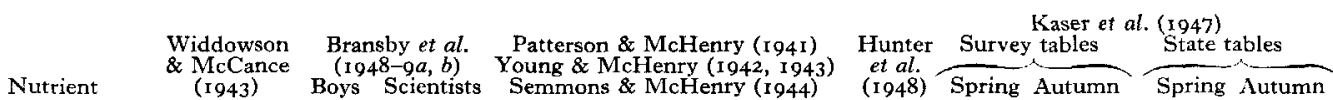

\begin{tabular}{|c|c|c|c|c|c|c|c|c|c|c|c|}
\hline \multirow{2}{*}{$\begin{array}{l}\text { Calories } \\
\text { Protein } \\
\text { Fat }\end{array}$} & \multicolumn{9}{|c|}{ (a) Percentage bias* } & \multirow{2}{*}{\multicolumn{2}{|c|}{8}} \\
\hline & $\begin{array}{c}(-1 \cdot 3) \\
7 \cdot 6\end{array}$ & $\begin{array}{r}1 \mathbf{I} \\
-6 \\
20\end{array}$ & $\begin{array}{r}(2) \\
-10 \\
(5)\end{array}$ & $\underset{10}{(-I \cdot 4)}$ & $(-2 \cdot 5)$ & $\underset{14}{(-2 \cdot 3)}$ & $(-0.4)$ & \multicolumn{2}{|c|}{ 10 } & & \\
\hline $\begin{array}{l}\text { Calcium } \\
\text { Iron }\end{array}$ & $\left(\begin{array}{c}-12 \\
(-3 \cdot 5)\end{array}\right.$ & $\begin{array}{r}15 \\
-18\end{array}$ & $\begin{array}{r}-7 \\
38\end{array}$ & -14 & $\begin{array}{l}-12 \\
(0.6)\end{array}$ & $(-6)$ & $\begin{array}{c}(10 \cdot 8) \\
22\end{array}$ & & & & \\
\hline $\begin{array}{l}\text { Vitamin A } \\
\text { Thiamine } \\
\text { Riboflavin } \\
\text { Nicotinic acid } \\
\text { Vitamin C }\end{array}$ & & & & $7 \cdot 6$ & 14 & 36 & $\begin{array}{l}60 \\
70 \\
(17) \\
(14) \\
\text { jo6 }\end{array}$ & $\begin{array}{r}28 \\
-34 \\
-22 \\
147\end{array}$ & $\begin{array}{r}72 \\
152 \\
-10 \\
-37 \\
356\end{array}$ & $\begin{array}{r}43 \\
-31 \\
71 \\
171\end{array}$ & $\begin{array}{r}43 \\
85 \\
-22 \\
27 \\
74\end{array}$ \\
\hline & & & & (b) $\mathrm{Coe}$ & ficient of & variation & & & & & \\
\hline $\begin{array}{l}\text { Calories } \\
\text { Protein } \\
\text { Fat }\end{array}$ & 8 & $\begin{array}{r}8 \\
6 \\
17\end{array}$ & $\begin{array}{r}7 \\
7 \\
17\end{array}$ & $\begin{array}{l}18 \\
24\end{array}$ & Io & $\begin{array}{l}22 \\
32\end{array}$ & 17 & & & & 6 \\
\hline $\begin{array}{l}\text { Calcium } \\
\text { Iron }\end{array}$ & $\begin{array}{r}9 \\
\text { I I }\end{array}$ & $\begin{array}{l}\text { I I } \\
\text { I I }\end{array}$ & $\begin{array}{l}12 \\
15\end{array}$ & 16 & I 8 & 18 & $\begin{array}{l}24 \\
34\end{array}$ & & & & \\
\hline $\begin{array}{l}\text { Vitamin A } \\
\text { Thiamine } \\
\text { Riboflavin } \\
\text { Nicotinic acid } \\
\text { Vitamin C }\end{array}$ & & & & ro & 14 & 19 & $\begin{array}{l}74 \\
57 \\
33 \\
55 \\
45\end{array}$ & $\begin{array}{r}146 \\
28 \\
\\
50 \\
216\end{array}$ & $\begin{array}{r}137 \\
565 \\
43 \\
74 \\
697\end{array}$ & $\begin{array}{r}97 \\
33 \\
\text { IOI } \\
293\end{array}$ & $\begin{array}{r}97 \\
349 \\
53 \\
48 \\
215\end{array}$ \\
\hline
\end{tabular}


from Canada, and the last from the U.S.A. Widdowson \& McCance (1943) studied the diets of six scientists, comparing analyses with calculations from their own well-known tables. Bransby, Daubney \& King (1948a,b) worked respectively on forty-nine children in an orphanage and on thirty-three scientists. The McHenry series (Patterson \& McHenry, I94I; Young \& McHenry, I942, I943; Semmons \& McHenry, 1944) gives analyses of twenty varied meals served in a university canteen, compared with nutrients calculated from one, two or three published tables. Hunter, Kastelic \& Ball (1948) evaluated eighteen hospital diets. Some of the more extreme diets have been omitted for certain calculations. Kaser, Steinkamp, Robinson, Patton \& Youmans (1947) studied typical diets of poor rural families in spring and autumn, comparing analyses with computations from two different tables. Their calorie estimations were done in a bomb calorimeter.

It is usually assumed that chemical analyses may be taken as accurate, but disagreements between estimates by different standard methods, listed for example by Kaser et al. (1947) shake confidence in this opinion. But there is no alternative to acceptance of analysis as the best guide we can get. In computing Table 5, the calculated value for each diet was expressed as a percentage of the analytical value. These percentages were then averaged, and the deviation of the mean figure from the ideal value of roo indicates how far the tables used tend to give results systematically too high or too low. These deviations are shown in Table 5 as percentage bias. Those shown in parentheses are not statistically significant on the number of diets analysed by the authors. Table 5 also shows the c.v. The English figures are comparable in that they derive from the same tables. The others give a conspectus of variation in tables as well as between tables and chemical findings. The c.v. for calories and protein is probably at least 10 , and for fat and mineral salts between Io and 20. In each instance big biases may also occur, indicating that the group concerned is eating foodstuffs of higher or lower average nutritive value than those used by the compilers of the standard tables. Such divergences are not surprising, when even a stable foodstuff like milk is known to display variations in composition in bulked supplies corresponding to c.v. values of 20 or more. With the vitamins, both the c.v. and the bias are usually so large that the tabular findings are not to be trusted. This verdict is in accord with knowledge of the variability of the vitamin content of raw foods, to say nothing of vastly different degrees of destruction according to methods of cooking.

There is some suggestion that the positive biases occur in the poorer groups, the orphanage boys and the rural Americans. This is what one might expect. When a food varies in price according to quality, there is presumably some correlation between price and nutritive value. According to Orr (1936), i lb. of beef cost $7^{\cdot 2 \mathrm{~d}}$. in group $I$ and $13 \mathrm{~d}$. in group 6 . The protein in beef as purchased varies from 8.8 to $22.4 \%$, according to cut (Plimmer, I92 I). The tables cannot properly take account of these differences, especially when foods of allegedly similar composition are grouped. An egg cost I.Id. in group I and $I \cdot 7 \mathrm{~d}$. in group 6 . It is customary to assume that every egg weighs $2 \mathrm{oz}$. Recent experience in Britain has brought home 
to every housewife the fallacy of this rule. Presumably group I got the smallest and stalest eggs.

\section{Errors in estimating foods eaten}

Methods of assessing foodstuffs eaten vary enormously. In some individual surveys all foods are weighed as served. Sometimes the subject records all food used in 'homely measures', cups, spoonfuls and the like. Sometimes retrospective questioning is used, with or without visible samples or models to jog memory and give precision to estimates of size of helpings. For family studies the choice of methods is more restricted. It may be left entirely to the housewife to record food passing into consumption, or there may be more or less intense supervision with weighing of stocks and purchases and checking of menus by an investigator.

On the relative precision of these methods there is much debate but very little quantitative data. This is because of formidable technical difficulties, since it is usually not possible to try two methods simultaneously on the same subjects. This is especially true in family studies, and the published comparisons of techniques seem to relate entirely to intakes of individuals. Bransby et al. (1948-9a) got their orphanage children to describe by questioning and to assess by homely measures their diets, which were also weighed. For major nutrients there was a positive bias for homely measures averaging about 7 , and a negative bias on questioning averaging about 3 , as compared with weighing of the diets. The c.v. values ranged from 5 to 10 . McHenry $e t$ al. (1945) assert that the homely measures' technique, as compared with weighing, introduces an error not likely to exceed $10 \%$. An elaborate series of co-operative studies was made in the United States by Young, Chalmers, Church, Clayton, Gates, Hagan, Steele, Tucker, Wertz \& Foster (1952). They compared the results of dietary records, dietary histories and $24 \mathrm{~h}$ recalls for varied groups of individuals. Unfortunately they present their findings only as the end-products of an inappropriate series of statistical operations, from which the c.v. and the bias can only be approximately inferred. Table 6 shows c.v. figures for a $24 \mathrm{~h}$ recall of food eaten as compared

Table 6. Coefficients of variation of nutrients in diet deduced from $24 \mathrm{~h}$ recall as compared with values estimated from 7-day record. (Young, Chalmers et al. 1952)

$\begin{array}{lccc}\text { Nutrient } & \begin{array}{c}\text { Pregnant } \\ \text { women }\end{array} & \text { Schoolchildren } & \text { Students } \\ \text { Calories } & \mathbf{2 3} & \mathbf{2 5} & 28 \\ \text { Protein } & \mathbf{2 3} & \mathbf{2 3} & \mathbf{2 8} \\ \text { Vitamin A } & 80 & 79 & \mathbf{1 4 1} \\ \text { Thiamine } & 37 & 31 & 40 \\ \text { Riboflavin } & 32 & 28 & 50 \\ \text { Nicotinic acid } & 23 & 34 & 43 \\ \text { Vitamin C } & 64 & 49 & \mathbf{5 2}\end{array}$


with a 7 -day written record, for twenty-eight pregnant women, fifty-one schoolchildren aged II-I 8 , and 87 students aged I $5-26$. These figures are typical of the other comparisons made by these workers. The c.v. values are substantial, being about $25 \%$ for major nutrients and considerably higher for the vitamins. There were also often substantial biases when one method was compared with another. The discrepancies between methods found by these American workers are much greater than those of Bransby et al. (1948-9a). These may partly be explained by another finding of the American team, that there is substantial variation in the results obtained by different interviewers on the same group of subjects.

None of these studies can throw much light on the importance of a possible bias owing to the disturbance in normal food habits caused by the fact of investigation. There is evidence on this point. For instance, the Ministry of Food: National Food Survey Committee (195 I) finds that housewives tend to have bigger stocks at the beginning than at the end of the week of diet recording. This may be an attempt to save trouble. Or it may be stocking up to 'put on a good show'. In family surveys, attempts at increasing precision by such methods as weighing every helping or otherwise disturbing normal household routine might easily be more than counterbalanced by distortion of normal dietary intakes. The Ministry of Food: National Food Survey Committee (1953) has recently decided to relax its previous detailed inventory of stocks in hand, presumably believing that the less the housewife is disturbed, the more typical the picture that emerges.

\section{Errors of sampling people}

A dietary survey is a social investigation of a most elaborate kind. Even the simplest type of survey, in which each subject is asked only one definite question, is beset with pitfalls which social scientists are just beginning to explore. The population-sampling errors of nutrition surveys may be most substantial and are certainly difficult to define and measure. Owing to the need to secure co-operative subjects, it is usually impossible to get anything like a random sample. In the Ministry of Food: National Food Survey Committee's (1952) study, for example, $18.5 \%$ of selected suitable addresses give no reply after three calls, $35.1 \%$ of the respondents refuse to co-operate, and only $46.4 \%$ accept. Of these, $8.6 \%$ drop out, leaving only $37.8 \%$ who return completed.records. These are known to be a biased sample, being for instance households with a larger average number of children. It also seems probable that women who stay at home will feed their families differently from those who are always out. The complacency of the National Food Survey about the representative character of its sample seems rather unjustified.

Further kinds of error may arise when the population is to be broken down into income groups or social classes. It is notoriously impracticable to find out the income coming into a house, and sometimes only a hazy idea can be obtained of the occupation of the breadwinner. Errors of classification must occur, but their seriousness is quite unknown. Such errors would tend to mask the contrast between the nutritional status of different sections of the community. Then there are psychological interactions between subject and interviewer. It has been demonstrated 
that even in a simple survey the interviewers tend to return varying results. Such effects are much more likely when the investigator is constantly calling on, and prying into the activities of, the housewife.

\section{Discussion}

It remains to assess the influence of all these sources of error acting jointly. For this purpose it is necessary to consider separately the effect of random sampling errors and of systematic error or bias. Suppose that a measurement, say the calorie intake of an individual, is subject to several kinds of sampling error, with c.v. values $a, b, c \ldots$, but that none of these errors involves bias. Provided the errors are not correlated, the mean of the observations will be a valid and efficient estimate of the true mean, and the joint c.v. will be $\left(a^{2}+b^{2}+c^{2} \ldots\right)^{\frac{1}{3}}$. Thus if the c.v. values for estimation of foods eaten and for translation into nutrient are each 10 , the joint effect has a c.v. of $10 \sqrt{ } 2$, or about 14 . If the sampling error due to limited period is also Io, the joint effect of all three will have a c.v. of $10 \sqrt{ } 3$, or about 17 . If one of the errors has a larger c.v. than the others, these latter make very little difference. Thus one error with a c.v. of to and two each having a c.v. of 5 compose to give a joint c.v. of $\sqrt{ } 150$, or about 12 . So there is not much point in straining overmuch to minimize one kind of error if others exist comparable or greater in size. If all errors are random and unbiased, the determination of the nutritional status of an individual or family unit will have the uncertainty indicated by the c.v., but the uncertainty attaching to the mean can be reduced to any required extent, in theory at least, by increasing sample size, according to the ordinary rule that the standard deviation of the mean is inversely proportional to the square root of the number of observations.

This rather comforting conclusion does not hold if bias is known or reasonably expected to be present. Suppose for example it is suspected that bias due to deviation of food composition from tabular values might raise or lower the mean by $5 \%$, this must be compounded with the random sampling error to get a true picture of the reliability of the mean. But bias has this important peculiarity, that its contribution to the uncertainty of the mean is the same whatever the sample size. In such a case, there is no point in taking very large samples, and gross selfdeception to imagine that the means of such samples are much more precise than those of smaller groups of observations. For instance, suppose the c.v. of a set of observations is 25 , and there is no bias. The c.v. of the mean for sample size 25 will be 5 , for sample size 100 it will be $2 \cdot 5$, and for sample size 2500 it will be 0.5 . Now suppose there is bias, of unknown direction in any particular case, but believed or feared to correspond to a c.v. of 10. For one observation the joint c.v. will be $\left(\mathrm{IO}^{2}+25^{2}\right)^{\frac{1}{2}}$ or about 26.9 , for 25 observations it will be $\left(\mathrm{IO}^{2}+5^{2}\right)^{\frac{1}{2}}$ or about $11 \cdot 2$, for 100 observations the c.v. will be about $10 \cdot 3$, and for larger sample sizes the c.v. cannot fall to less than ro. In such a case a sample size of between $5^{\circ}$ and roo would supply virtually all the precision obtainable, though larger numbers might be justified if the representative character of the sample 
could be thereby enhanced, or if estimates were wanted for subgroups of the population.

The practical conclusions that emerge seem to be as follows. If dietary surveys are regarded as a fairly rough instrument, they can legitimately be used for estimating the average intake of calories and major nutrients of defined groups, though they are of little value for assessing the nutritional status of individuals or the proportion of persons above or below a defined level far removed from the mean. For vitamins the dietary survey is not reliable. There is no point in having very big samples, but every reason to make extreme efforts to get fair sampling and a low proportion of refusals to co-operate. The very laborious weighing method, which costs several times as much to operate as the price of the food consumed, probably need not be insisted on if food tables, involving a comparable or bigger error, are used, and if the period of study is short. But further research is needed on these and other points of technique. Workers carrying out such research, either as a special study or as an ancillary to a dietary survey, if they insist on carrying out analyses of variance and other elaborate and uninformative statistical computations, should also report their observations in such a way that simple averages, c.v. values and biases can be directly inferred.

\section{SUMMARY}

From data in the literature of dietary surveys computations have been made of the errors associated with various phases of the technique of dietary survey, including the sampling of persons and of period of investigation, the estimation of the foodstuffs eaten, and the calculation of the nutrient content of the diet. Each phase of technique involves random errors, expressible as the coefficient of variation about the mean, and bias, expressible as the difference between the estimated and the putative true mean. The errors are so large as to make the dietary survey no more than a rather rough instrument. The practical implications of these findings are discussed.

\section{REFERENCES}

Bigwood, E. J. (1939). Guiding Principles for Studies on the Nutrition of Populations. Geneva: League of Nations Health Organization.

Boulton, F. N. (1945). Unpublished, quoted by Widdowson (1947).

Bransby, E. R., Daubney, C. G. \& King, J. (1948-9a). Brit. $\mathcal{~}$. Nutr. 2, 89

Bransby, E. R., Daubney, C. G. \& King, J. (1948-9b). Brit. $\mathscr{~}$. Nutr. 2, 232.

Hobson, W. (1948). F. Hyg., Camb., 46, I98.

Hunter, G., Kastelic, J. \& Ball, M. (I948). Canad. F. Res. Sect. E, 26, 367.

Kaser, M. M., Steinkamp, R. C., Robinson, W. D., Patton, E. W. \& Youmans, J. B. (1947). Amer. F. Hyg. 46, 297.

Leitch, I. \& Aitken, F. C. (1949-50). Nutr. Abstr. Rev. 19, 507.

McCance, R. A. \& Widdowson, E. M. (1946). Spec. Rep. Ser. med. Res. Coun., Lond., no. 235, 2 nd ed.

McHenry, E. W., Ferguson, H. P. \& Gurland, J. (1945). Canad. F. Publ. Hlth, 36, 355.

Ministry of Food: National Food Survey Committee (195I). The Urban Working-Class Household Diet, 1940 to 1949. London: H.M. Stationery Office.

Ministry of Food: National Food Survey Committee (1952). Domestic Food Consumption and Expenditure, 1950. London: H.M. Stationery Office.

Ministry of Food: National Food Survey Committee (r953). Domestic Food Consumption and Expenditure, I95I. London: H.M. Stationery Office. 
National Research Council (1949). Bull. nat. Res. Coun., Wash., no. I17.

Norris, T. (1949). Dietary Surveys, their Technique and Interpretation. Washington, D.C.: Food and Agriculture Organization of the United Nations.

Orr, J. B. (1936). Food, Health and Income. London: Macmillan and Co. Ltd.

Patterson, J. M. \& McHenry, E. W. (194I). Canad. F. Publ. Hlth, 32, 362.

Pearson, K. (1922). Tables of the Incomplete T-Function. London: Biometrika Office.

Plimmer, R. H. A. (1921). Analyses and Energy Values of Foods. London: H.M. Stationery Office.

Potts, T. N. V. (1939). Report on a Study of the Diets of $20_{5}$ Families in the West Riding of Yorkshire. Wakefield, Yorks: County Council of the West Riding of Yorkshire.

Semmons, E. M. \& McHenry, E. W. (1944). Canad. F. Publ. Hlth, 35, 286.

Widdowson, E. M. (1936). F. Hyg., Camb., 36, 269.

Widdowson, E. M. (1947). Spec. Rep. Ser. med. Res. Coun., Lond., no. 257.

Widdowson, E. M. \& McCance, R. A. (1936). F. Hyg., Camb., 36, 293.

Widdowson, E. M. \& McCance, R. A. (r943). Lancet, 244, 230.

Young, C. M., Chalmers, F. W., Church, H. N., Clayton, M. M., Gates, L. O., Hagan, G. C., Steele, B. F., Tucker, R. E., Wertz, A. W. \& Foster, W. D. (1952). Bull. Mass. agric. Exp. Sta. no. 469.

Young, M. C., Franklin, R. E., Foster, W. D. \& Steele, B. F. (1952). In Bull. Mass. agric. Exp. Sta. no. 469, p. 49 .

Young, C. M. \& McHenry, E. W. (1942). Canad. F. Publ. Hlth, 33, 224.

Young, C. M. \& McHenry, E. W. (1943). Canad. F. Publ. Hlth, 34, 367.

Yudkin, J. (1951). Brit. $\mathcal{F}$. Nutr. 5, 177.

\title{
Infant-feeding Practices
}

\section{Breast Feeding and the Prevention of Infant Malnutrition}

\author{
By B. S. Platt, Human Nutrition Research Unit, Medical Research Council \\ Laboratories, Holly Hill, London, N.W.3
}

Malnutrition contributes to the appallingly high death rates still to be found in many parts of the world among infants and young children and is the cause of much sickness and ill-health, some of which persists into later life. The recognition of the ubiquity of malnutrition in infants and young children has led to the present interest in infant-feeding practices.

Amongst those peoples in whom malnutrition is prevalent, life is for the most part simple and somewhat naturalistic. It is difficult to find a term to describe these communities; the words 'primitive', 'backward' and 'underdeveloped' are frequently used but none of them is entirely appropriate to such a variety of cultures as is found in large parts of Africa, in the Far East including India and China, and in the Australian bush. For example, many African communities are described as 'primitive', but the majority have a prehistory, if not a history, longer than our own (Sigerist, I95 I) and they are composed of settled peoples with agricultural or pastoral pursuits; the term can, however, be more correctly applied to the aborigines of Australia who are among the hunting races and are still at the food-gathering stage of evolution; the civilizations of some of the Far Eastern countries are, of course, amongst the oldest in the world. I shall therefore refer to these communities as 'unsophisticated'; this term also has the merit of applying to some features of their usual infant-feeding practices.

Provision for the health and well-being of the child should of course begin with 